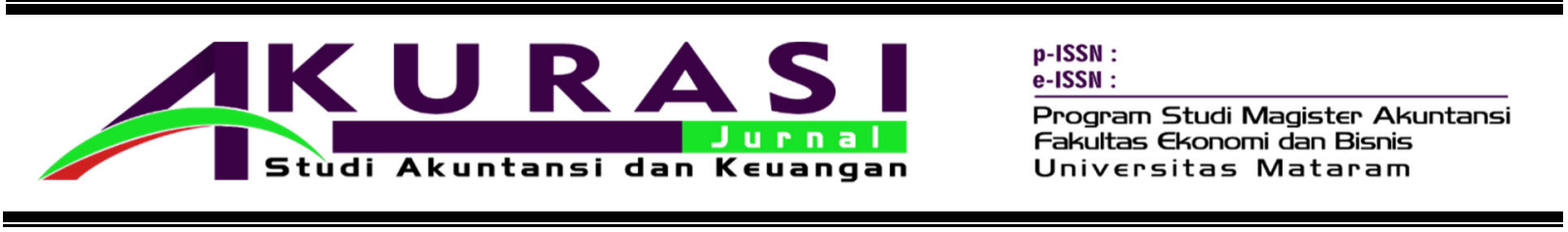

\title{
DETERMINAN MANAJEMEN LABA DAN DAMPAKNYA TERHADAP RELEVANSI NILAI INFORMASI AKUNTANSI: PENGUJIAN PERAN GOOD CORPORATE GOVERNANCE
}

\author{
Resti Kartika Dewi \\ National Slum Upgrading Program (NSUP) Provinsi NTB \\ restimochti@gmail.com
}

\section{INFORMASI ARTIKEL}

Article history:

Dikirim tanggal: 08-11-08

Revisi pertama tanggal: 07-1-2019

Diterima tanggal: 15-1-2019

Tersedia online tanggal $\mathrm{dd} / \mathrm{mm} /$ yyyy

\begin{abstract}
A BS TRAK
Penelitian ini bertujuan untuk menganalisis determinan manajemen laba dan dampaknya terhadap relevansi nilai informasi akuntansi serta peran good corporate governance $(G C G)$ sebagai variabel pemoderasi. Sampel penelitian adalah 62 perusahaan manufaktur yang terdaftar di Bursa Efek Indonesia (BEI) periode 2016 Hasil penelitian ini menunjukkan bahwa kinerja keuangan dan struktur kepemilikan berpengaruh positif dan signifikan terhadap manajemen laba sementara karakteristik perusahaan berpengaruh positif tetapi tidak signifikan. Hasil lain menunjukkan bahwa manajemen laba dengan indikator short term discretionary accruals dan long term discretionary accruals merupakan indikator dari manajemen laba yang paling berpengaruh terhadap relevansi nilai informasi akuntansi dan good corporate governance terbukti memperlemah pengaruh manajemen laba terhadap relevansi nilai informasi akuntansi. Implikasi penelitian ini dapat berguna sebagai dasar masukan dan pertimbangan bagi pengguna laporan keuangan khususnya investor dalam melakukan pengambilan keputusan investasi. Bagi pihak manajemen, hasil penelitian dapat dijadikan sebagai bahan pertimbangan dalam penyusunan rencana kegiatan perusahaan dan bagi pemerintah dalam menetapkan kebijakan pajak.
\end{abstract}

Kata kunci: short term discretionary accruals, long term discretionary accruals, aktivitas riil, relevansi nilai informasi akuntansi, good corporate governance

\section{ABSTRACT}

This study aims to analyze the determinants of earnings management and its impact on value relevance of accounting information and the role of good corporate governance $(G C G)$ as a moderating variable. The samples of this research is 62 manufacturing companies listed in Indonesia Stock Exchange (IDX) period 2016. The results of this study showed that financial performance and ownership structure have a positive and significant impact on earnings management while firm characteristics have positive but not significant. Other results showed that earnings management with short term discretionary accruals and long term discretionary accruals indicator of earnings management most influential on the value relevance of accounting information and good corporate governance proved to reduce the influence of earnings management on the value relevance of accounting information. The implications of this study can be useful as a basis for input and consideration for users of financial statements, especially investors in making investment decisions. For the management, the results of research can be used as consideration in the preparation of corporate activity plans and for the government in setting tax policy.

Keywords: short term discretionary accruals, long term discretionary accruals, real activity, value relevance of accounting information, good corporate governance 


\section{Pendahuluan}

Laporan keuangan merupakan bagian utama dalam pelaporan yang dapat dijadikan sarana penting untuk mengomunikasikan informasi kepada pihak-pihak yang berkepentingan terhadap perusahaan, baik internal maupun eksternal. Pada dasarnya semua elemen dalam laporan keuangan penting bagi pengguna, namun kecenderungan dari pengguna tersebut lebih terfokus pada informasi laba yang disajikan perusahaan (Halim, Carmel dan Tobing, 2005). Angka laba yang menjadi sorotan para pengguna laporan keuangan menjadi krusial ketika laba tersebut terpengaruh oleh komponen laba yang masih dapat dipengaruhi oleh diskresi atau kebijakan manajemen.

Manajemen laba (earnings management) merupakan fenomena yang sulit untuk dihindari karena fenomena ini merupakan dampak dari penggunaan dasar akrual dalam penyusunan laporan keuangan (Trisnawati, Wiyadi dan Noer, 2012). Penggunaan dasar akrual dalam penyusunan laporan keuangan tidak menutup kemungkinan bahwa fenomena manajemen laba ini dapat terjadi pada perusahaan publik di seluruh dunia, baik pada pasar modal negara berkembang maupun pada pasar modal negara maju. Dalam hubungan antara agent dan principal, akan timbul masalah jika terdapat informasi yang asimetri (information asymetry). Hal ini menyebabkan agent cenderung melakukan perilaku yang tidak semestinya (disfunctional behaviour). Salah satu disfunctional behaviour yang dilakukan agent adalah pemanipulasian data dalam laporan keuangan agar sesuai dengan harapan principal meskipun laporan tersebut tidak menggambarkan kondisi perusahaan yang sebenarnya. Dalam hubungannya dengan kinerja, laporan keuangan sering dijadikan dasar untuk penilaian kinerja perusahaan.

Selain dari faktor kinerja keuangan, terdapat faktor lain yang mempengaruhi manajemen laba yakni karakteristik perusahaan. Karakteristik perusahaan mendapat perhatian penting dalam penelitian ini karena peneliti bertitik tolak dari pemikiran bahwa motivasi untuk meningkatkan kepercayaan publik yang dilakukan oleh perusahaan akan sangat ditentukan oleh karakteristik-karakteristik tertentu dari perusahaan yang bersangkutan. Strategi diversifikasi perusahaan sebagai salah satu indikator karakteristik perusahaan membuka peluang adanya pemisahan kepemilikan saham oleh principal dengan agent dan pihak eksternal lainnya. Adanya pemisahan kepemilikan saham oleh principal dengan pihak lainnya dalam suatu organisasi cenderung menimbulkan konflik keagenan. Kepemilikan saham oleh pihak eksternal ini dapat mengontrol terjadinya manajemen laba.

Penelitian tentang dampak manajemen laba terhadap relevansi nilai informasi akuntansi pernah dilakukan oleh beberapa peneliti berikut namun dengan hasil penelitian yang berbeda-beda. Whelan dan McNamara (2004) meneliti tentang pengaruh manajemen laba terhadap relevansi nilai informasi akuntansi. Hasil penelitian menunjukkan bahwa manajemen laba melalui akrual jangka panjang memiliki pengaruh yang lebih besar terhadap relevansi nilai informasi akuntansi laba dan nilai buku dari pada manajemen laba melalui akrual jangka pendek. Penelitian sejenis yang dilakukan oleh Sholihah (2013), Kusuma (2006) dan Apriyan dan Pasaribu (2015) mendukung hasil penelitian tersebut. Berbeda dengan hasil penelitian sebelumnya, penelitian yang dilakukan oleh Fattahi et al. (2014) menunjukkan bahwa manajemen laba tidak berpengaruh terhadap relevansi nilai informasi akuntansi.

Salah satu cara yang digunakan untuk memonitor masalah kontrak dan membatasi perilaku oportunistik manajemen adalah corporate governance $(C G)$. Penelitian yang dilakukan oleh Shan (2014) menunjukkan bahwa good corporate governance (GCG) mampu membatasi pengaruh manajemen laba terhadap relevansi nilai informasi akuntansi. Good corporate governance (GCG) dalam penelitian Shan (2014) tersebut diukur menggunakan konsentrasi kepemilikan, konsentrasi kepemilikan asing, ukuran dewan 
direksi, ukuran dewan komisaris, ukuran komisaris independen, ukuran dewan komisaris profesional, komite audit independen dan auditor big four.

Berdasarkan latar belakang di atas, maka tujuan penelitian ini adalah untuk menguji dan memberikan bukti empiris mengenai pengaruh determinan manajemen laba dan dampaknya terhadap relevansi nilai informasi akuntansi serta peran good corporate governance $(G C G)$ sebagai variabel pemoderasi. Hasil penelitian ini dapat menjadi referensi dan data tambahan bagi peneliti-peneliti lainnya yang tertarik pada bidang kajian manajemen laba yang terkait dengan teori keagenan dan teori pensinyalan. Hasil penelitian ini juga dapat dijadikan sebagai dasar masukan dan pertimbangan bagi pengguna laporan keuangan khususnya investor dan kreditor dalam melakukan pengambilan keputusan investasi dan pendanaan. Bagi pihak manajemen, hasil penelitian ini dapat dijadikan sebagai bahan pertimbangan dalam penyusunan rencana kegiatan perusahaan di periode yang akan datang dan untuk mengatur aktivitas perusahaan.

\section{Kerangka Teoretis Dan Pengembangan Hipotesis} Agency Theory dan Signaling Theory

Teori keagenan menggambarkan perusahaan sebagai suatu titik temu antara pemilik perusahaan dengan manajemen. Pada praktiknya, konflik kepentingan antara prinsipal dan agent muncul ketika terjadi benturan kepentingan dan perbedaan tujuan yang ingin dicapai oleh prinsipal sebagai pemilik perusahaan dan agent sebagai pihak yang mengelola perusahaan. Pemanipulasian terhadap kondisi perusahaan berpotensi dapat dilakukan agen dilatarbelakangi adanya perbedaan informasi yang dimiliki oleh principal dan agent. Sebagai pengelola perusahaan, agent lebih mengetahui keadaan yang terjadi di dalam perusahaan daripada principal. Keadaan tersebut dikenal sebagai asimetri informasi (information asymmetry). Asimetri informasi antara manajer dengan pemilik dapat memberikan kesempatan bagi manajer untuk melakukan manajemen laba (Richardson, 2000).

Signaling Theory menjelaskan bahwa pemberian sinyal dilakukan oleh manajer untuk mengurangi asimetri informasi. Manajer memberikan informasi melalui laporan keuangan bahwa mereka menerapkan kebijakan akuntansi konservatisme yang menghasilkan laba yang lebih berkualitas karena prinsip ini mencegah perusahaan melakukan tindakan membesar-besarkan laba dan membantu pengguna laporan keuangan dengan menyajikan laba dan aktiva yang tidak overstate (Jamaan, 2008).

\section{Rerangka Konseptual Penelitian}

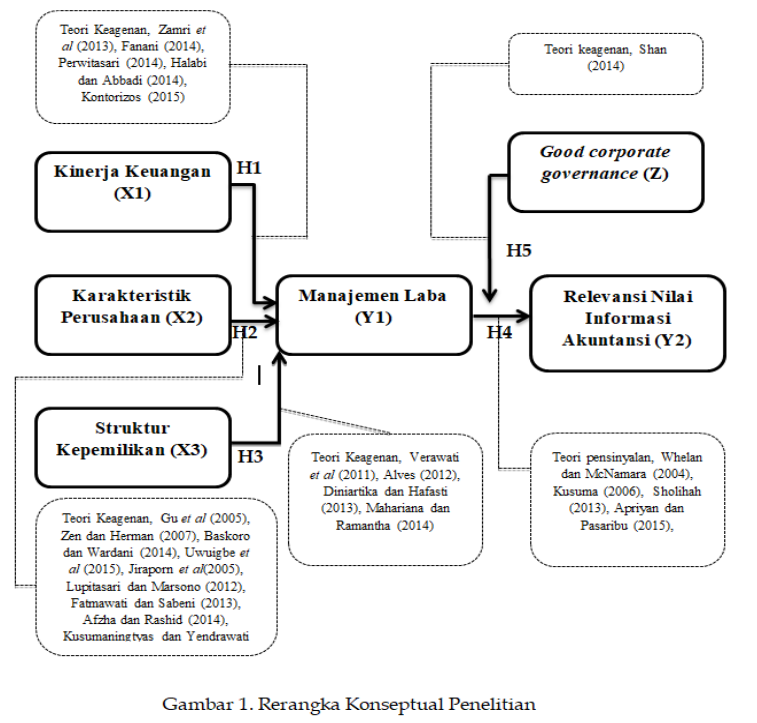




\section{Pengaruh Kinerja Keuangan terhadap Manajemen Laba}

Menurut Watts dan Zimmerman (1986) hubungan principal dan agent sering ditentukan dengan angka akuntansi. Hal ini memicu agent untuk memikirkan bagaimana angka akuntansi tersebut dapat digunakan sebagai sarana untuk memaksimalkan kepentingannya. Analisis dan interpretasi dari macam-macam rasio dapat memberikan pandangan yang lebih baik tentang kondisi keuangan dan prestasi perusahaan daripada analisis yang hanya didasarkan atas data keuangan yang tidak berbentuk rasio. Kinerja perusahaan diukur berdasarkan berbagai macam rasio seperti solvabilitas, profitabilitas, likuiditas dan aktivitas. Studi Zamri et al. (2013) menemukan leverage atau tingkat utang memiliki hubungan yang negatif terhadap manajemen laba, yang menunjukkan bahwa leverage adalah salah satu pengendali dan sistem monitoring yang dapat membatasi manajemen laba. Studi Kontorizos (2015) menemukan leverage memiliki hubungan yang positif terhadap manajemen laba, yang mendukung teori akuntansi positif yang menunjukkan makin dekat suatu perusahaan terhadap pelanggaran pada akuntansi yang didasarkan pada kesepakatan utang, maka kecenderungannya adalah semakin besar kemungkinan manajer perusahaan memilih prosedur akuntansi dengan perubahan laba yang dilaporkan dari periode masa depan ke periode masa kini. Fanani (2014) dan Perwitasari (2014) menemukan bahwa profitabilitas berpengaruh positif terhadap manajemen laba. Hasil penelitian menunjukkan bahwa manajemen melakukan tindakan manajemen laba agar kinerja perusahaan terlihat lebih baik sesuai dengan ekspektasi manajemen. Sejalan dengan studi sebelumnya, Halabi dan Abbadi (2014) menemukan bahwa profitabilitas berpengaruh terhadap manajemen laba yang terjadi di Bursa Efek Amman, yang mengindikasikan banyak item-item akuntansi yang terdistorsi oleh akuntan untuk mengeksploitasi fleksibilitas International Financial Reporting Standards (IFRS). Kinerja perusahaan sebagai tolok ukur bagi para investor untuk melihat perkembangan perusahaan membuat manajer akan melakukan berbagai cara untuk menampilkan kinerja terbaiknya. Rasio-rasio keuangan yang menjadi tolok ukur kinerja keuangan dapat menjadi indikasi terjadinya manajemen laba sehingga diajukan hipotesis sebagai berikut:

\section{$\mathrm{H}_{1}$ : Kinerja keuangan berpengaruh terhadap manajemen laba}

\section{Pengaruh Karakteristik Perusahaan terhadap Manajemen Laba}

Setiap perusahaan pasti memiliki motivasi untuk meningkatkan kepercayaaan publik terhadap pencapaian usaha perusahaan. Penilaian terhadap setiap perusahaan akan berbeda tergantung pada kondisi dan karakteristik perusahaan tersebut dan pada penelitian ini dilihat berdasarkan variabel yang berkaitan dengan pasar seperti ukuran perusahaan, pertumbuhan perusahaan, umur perusahaan, volatilitas laba dan diversifikasi perusahaan. Banyak unsur yang menjadi sorotan bagi publik dalam melakukan penilaian atas perusahaan. Karakteristik perusahaan sebagai tolok ukur untuk melihat perkembangan perusahaan, membuat manajer akan melakukan berbagai cara untuk menampilkan kinerja terbaiknya guna mendapat kepercayaan publik. Dengan demikian hipotesis kedua yang diajukan peneliti dalam penelitian ini adalah :

\section{$\mathrm{H}_{2}$ : Karakteristik perusahaan berpengaruh terhadap manajemen laba}

\section{Pengaruh Struktur Kepemilikan terhadap Manajemen Laba}

Manajemen laba muncul sebagai dampak persoalan keagenan dimana terjadi ketidakselarasan kepentingan antar pemilik dan manajemen. Hubungan antara principal dan agent dapat mengarah pada kondisi ketidak seimbangan informasi karena agent mempunyai posisi yang memiliki informasi yang lebih banyak tentang perusahaan dibandingkan principal. Informasi yang disampaikan terkadang tidak sesuai dengan kondisi perusahaan yang sebenarnya (Beneish, 2001). Salah satu mekanisme yang 
digunakan untuk mencoba menurunkan konflik yang disebabkan oleh pemisahan kepemilikan dan kontrol diantara kedua belah pihak adalah dengan menawarkan manajer untuk berpartisipasi dalam program opsi saham yang dikenal sebagai kompensasi berbasis saham (stock-based compensation). Pemberian kompensasi ini untuk manajer akan mengakibatkan peningkatan kepemilikan manajerial (Prempanichnukul dan Krittaya, 2012).

Berdasarkan uraian di atas maka dapat diargumentasikan bahwa manajemen laba terjadi karena adanya agentcy conflicts, yang muncul karena terjadinya pemisahan antara kepemilikan dengan pengelolaan perusahaan. Agentcy conflicts ini dapat dikontrol dengan adanya struktur kepemilikan yang menggambarkan komposisi kepemilikan saham dari suatu perusahaan. Dengan demikian hipotesis ketiga yang diajukan peneliti dalam penelitian ini adalah:

\section{$\mathrm{H}_{3}$ : Struktur kepemilikan berpengaruh terhadap manajemen laba}

\section{Pengaruh Manajemen Laba terhadap Relevansi Nilai Informasi Akuntansi}

Menurut Jogiyanto (2000: 392), informasi yang dipublikasikan sebagai suatu pengumuman akan memberikan sinyal bagi investor dalam pengambilan keputusan investasi. Jika pengumuman tersebut mengandung nilai positif, maka diharapkan pasar akan bereaksi pada waktu pengumuman tersebut diterima oleh pasar. Pada waktu informasi diumumkan dan semua pelaku pasar sudah menerima informasi tersebut, pelaku pasar terlebih dahulu menginterpretasikan dan menganalisis informasi tersebut sebagai sinyal baik (good news) atau sinyal buruk (bad news). Jika pengumuman informasi tersebut sebagai sinyal baik bagi investor, maka terjadi perubahan dalam volume perdagangan saham.

Manajer perusahaan memberikan sinyal kabar baik maupun sinyal kabar buruk kepada pihak luar perusahaan. Jika kinerja perusahaan buruk, manajer melakukan manajemen laba untuk memberikan sinyal kabar buruk dengan tujuan memberikan informasi kepada pasar bahwa manajer mempunyai integritas, bertindak jujur, dan mempunyai keyakinan dapat mengatasi masalah yang dihadapi. Selain untuk menunjukkan kualitas manajerial, dengan memberikan sinyal buruk sebagaimana adanya, manajer berharap memperoleh apresiasi pasar untuk menahan penurunan harga saham perusahaan (Widyaningdyah dan Listiyana, 2009). Komponen penting dalam laporan keuangan yang seringkali dijadikan sebagai alat untuk menginformasikan kinerja perusahaan adalah laba dan nilai buku. Masalah akan terjadi ketika relevansi laba dan nilai buku sebagai alat pengukur kinerja perusahaan dihadapkan dengan praktek manipulasi (earnings management) yang dilakukan manajer (Kusuma, 2006). Scott (2006:137) mengatakan bahwa konsep relevansi nilai informasi akuntansi menjelaskan tentang bagaimana reaksi investor saat pengumuman informasi akuntansi yang terdapat pada laporan keuangan. Reaksi dari investor akan membuktikan bahwa kandungan informasi akuntansi merupakan isu yang sangat penting dalam proses pertimbangan pengambilan keputusan investasi.

Berdasarkan uraian di atas maka dapat diargumentasikan bahwa relevansi laba suatu perusahaan yang terindikasi melakukan earnings management seharusnya akan lebih rendah dari perusahaan yang tidak melakukan earnings management. Dengan demikian hipotesis keempat yang diajukan peneliti dalam penelitian ini adalah:

$\mathrm{H}_{4}$ : Manajemen laba berpengaruh terhadap relevansi nilai informasi akuntansi.

\section{Pengaruh Good Corporate Governance dalam memoderasi Hubungan Manajemen Laba terhadap Relevansi Nilai Informasi Akuntansi}

Jensen dan Meckling (1976) menyatakan bahwa teori keagenan mendeskripsi pemegang saham sebagai prinsipal dan manajemen sebagai agen. Filosofi yang mendasari 
kepentingan manajemen adalah kebutuhan akan harmonisasi dan sistematisasi dari manajemen dalam rangka menghasilkan kinerja yang efektif dan efisien. Sebagai bagian integral dari perusahaan, pihak manajemen yang ingin mencapai bentuk sistem yang teratur tentunya akan membutuhkan penerapan GCG secara konsisten (Veno, 2015).

Good Corporate Governance ( $G C G$ ) jika dikaitkan dengan praktik manajemen laba seharusnya dapat mengontrol praktik manajemen laba yang bersifat realistis sehingga menciptakan nilai tambah bagi perusahaan atau menahan praktik manajemen laba yang bersifat oportunis. Menurut Wini dan Astika (2014) nilai tambah yang diterima oleh perusahaan seperti; mudah untuk meningkatkan modal, biaya modal yang lebih rendah peningkatan kinerja bisnis dan kinerja ekonomi yang membaik serta memberikan dampak yang baik untuk harga saham. Penelitian Shan (2014) mendukung teori tersebut dimana hasil penelitian menunjukkan bahwa dampak negatif dari relevansi nilai untuk perusahaan yang bergerak di manajemen laba lebih besar dari perusahaan tanpa keterlibatan manajemen laba, dan perusahaan dengan praktik tata kelola perusahaan yang baik lebih mungkin untuk mengontrol manajemen laba yang bersifat realistis dan membatasi manajemen laba yang bersifat oportunis.

Berdasarkan uraian di atas maka dapat diargumentasikan bahwa perusahaan dengan tata kelola perusahaan yang baik diharapkan memiliki keunggulan kompetitif yang lebih baik daripada perusahaan dengan tata kelola perusahaan yang buruk sehingga mampu mengontrol praktik manajemen laba yang bersifat realistis dan menahan praktik manajemen laba yang bersifat oportunis yang berdampak pada relevansi nilai informasi akuntansi. Dengan demikian dirumuskan hipotesis kelima sebagai berikut:

\section{H5: Good Corporate Governance memoderasi hubungan manajemen laba terhadap relevansi nilai informasi akuntansi}

\section{Metode Penelitian}

\section{Populasi dan Sampel Penelitian}

Populasi dalam penelitian ini adalah seluruh perusahaan manufaktur yang terdaftar di Bursa Efek Indonesia pada tahun 2016. Sampel ditentukan menggunakan metode purposive sampling sebagai berikut:

Tabel 1. Kriteria Pemilihan Sampel

\begin{tabular}{lc}
\hline \multicolumn{1}{c}{ Keterangan } & Jumlah Perusahaan \\
\hline $\begin{array}{l}\text { Perusahaan manufaktur yang terdaftar di Bursa Efek Indonesia (BEI) } \\
\text { pada tahun 2016 }\end{array}$ & 83 \\
$\begin{array}{l}\text { Perusahaan manufaktur yang tidak menggunakan mata uang Rupiah } \\
\text { dalam pelaporan keuangannya }\end{array}$ & $(15)$ \\
Perusahaan yang tidak memiliki data lengkap & $(6)$ \\
\hline \multicolumn{1}{c}{ Total Observasi } & 62 \\
\hline \multicolumn{1}{c}{ Sumber: }
\end{tabular}

\section{Pengukuran Variabel.}

Penelitian ini menggunakan variabel endogen manajemen laba dan relevansi nilai informasi akuntansi, sedangkan variabel eksogen adalah kinerja keuangan, karakteristik perusahaan dan struktur kepemilikan, sedangkan Good Corporate Governance (GCG) merupakan variabel moderating. Definisi operasional dan pengukuran masing-masing variabel dijelaskan berikut ini. 


\section{a. Manajemen Laba.}

Manajemen laba dalam penelitian ini diukur dengan menggunakan model dirumuskan oleh Whelan dan McNamara (2004) dengan menggunakan Short Term Discretionary Accruals, Long Term Discretionary Accruals dan aktivitas riil.

Pengukuran Manajemen Laba Short Term Discretionary Accruals

ACCit = EARNit - CFOit

Keterangan:

ACCit : Total akrual perusahaan i pada tahun $\mathrm{t}$

EARNit : Laba sebelum pos luar biasa perusahaan i pada tahun $\mathrm{t}$

CFOit : Kas dari operasi perusahaan i pada tahun $\mathrm{t}$

STACCi,t $=\Delta A R i t+\Delta I N V i t+\Delta O C A i t-\triangle A P i t-\triangle T$ XPit $-\triangle O C L i t$

Keterangan

STACCi,t : Short term accruals perusahaan i pada tahun $\mathrm{t}$

$\triangle$ ARit $\quad$ : Piutang dagang tahun $\mathrm{t}$ dikurangi piutang tahun $\mathrm{t}-1$ perusahaan $\mathrm{i}$

$\triangle I N V i t \quad:$ Persediaan tahun $\mathrm{t}$ dikurangi persediaan tahun $\mathrm{t}-1$ perusahaan $\mathrm{i}$

$\triangle O C$ Ait $\quad$ : Aktiva lancar lainnya tahun $\mathrm{t}$ dikurangi aktiva lancar perusahaan $\mathrm{i}$

$\triangle$ APit $\quad$ : Hutang dagang tahun $\mathrm{t}$ dikurangi hutang dagang tahun $\mathrm{t}-1$ perusahaan $\mathrm{i}$

$\triangle T X P i t \quad$ : Hutang pajak tahun $\mathrm{t}$ dikurangi hutang pajak tahun $\mathrm{t}-1$ perusahaan $\mathrm{i}$

$\triangle$ OCLit : Hutang lancar lainnya $\mathrm{t}$ dikurangi hutang lancar lainnya tahun $\mathrm{t}-1$ perusahaan $\mathrm{i}$

Pengukuran Manajemen Laba Long Term Discretionary Accruals

Sesuai dengan definisi total accruals, yaitu gabungan short-term dan long-term accruals, maka long-term accruals dicari dengan mengurangkan total accruals dengan shor-term accruals.

\section{LTACCit $=$ ACCit - STACCit}

Keterangan

LTACCit : Long term accruals perusahaan i pada tahun $\mathrm{t}$

ACCit : Total accruals perusahaan i pada tahun $\mathrm{t}$

STACCit : Short term accruals perusahaan i pada tahun $\mathrm{t}$

Model Jones (1991) digunakan untuk mengestimasi total discretionary accruals dengan formula sebagai berikut.

$\frac{A C C i t}{T A i, t-1}=\varphi 1\left(\frac{1}{T A i, t}\right)+\varphi 2\left(\frac{\Delta R E V i, t}{T A i, t-1}\right)+\varphi 3\left(\frac{P P E i, t}{T A i, t-1}\right)+\varepsilon \mathrm{i}, \mathrm{t}$

Keterangan

ACCit : Total accruals perusahaan i pada tahun $\mathrm{t}$

TA i,t-1 : Total aktiva perusahaan i pada tahun $\mathrm{t}-1$

$\triangle R E V i t \quad$ : Pendapatan tahun t dikurangi pendapatan tahun $\mathrm{t}-1$ perusahaan $\mathrm{i}$

PPEit : Nilai bruto tanah, bangunan dan peralatan perusahaan i pada tahun $\mathrm{t}$

Eit $\quad$ : e rror untuk perusahaan $\mathrm{i}$ tahun $\mathrm{t}$

Koefisien estimasi dari persamaan $4\left(\varphi_{1}, \varphi_{2}, \varphi_{3}\right)$ digunakan untuk menghitung akrual yang diharapkan untuk tiap-tiap perusahaan. Karena estimasi tersebut diasumsikan 
menggambarkan non discretionary accruals, perbedaan dengan estimasi di atas dengan akrual sebenarnya dianggap total discretionary accruals (DACC).

DACC $\mathrm{i}, \mathrm{t}=\frac{A C C i t}{T A i, t-1}-\left[\mathrm{j} 1\left(\frac{1}{T A i, t-1}\right)+\mathrm{j} 2\left(\frac{\Delta R E V i, t}{T A i, t-1}\right)+\mathrm{j} 3\left(\frac{P P E i, t}{T A i, t-1}\right)\right]$

Short term accruals yang diharapkan untuk industri diukur dengan komponen pendapatan model Jones (1991).

$\frac{S T A C C i, t}{T A i, t-1}=\gamma 1\left(\frac{1}{T A i, t-1}\right)+\gamma 2\left(\frac{\Delta R E V i, t}{T A i, t-1}\right)+\varepsilon \mathrm{i}, \mathrm{t}$

Keterangan

STACCit : Short term accruals perusahaan i pada tahun $\mathrm{t}$ (dari persamaan 2)

TA i,t-1 : Total aktiva perusahaan i pada tahun $\mathrm{t}-1$

$\triangle R E V i t \quad$ : Pendapatan tahun $\mathrm{t}$ dikurangi pendapatan tahun $\mathrm{t}-1$ perusahaan $\mathrm{i}$

Eit $\quad$ : error untuk perusahaan $\mathrm{i}$ tahun $\mathrm{t}$

Sama halnya dengan menghitung total discretionary accruals, perbedaan estimasi persamaan 6 dengan short term accruals sebenarnya dianggap short term discretionary accruals (STDACC).

STDACC $\mathrm{i}, \mathrm{t}=\frac{S T A C C i, t}{T A i, t-1}-\left[\mathrm{g} 1\left(\frac{1}{T A i, t-1}\right)+\operatorname{g2}\left(\frac{\Delta R E V i, t}{T A i, t-1}\right)\right]$

Estimasi long term accruals yang diharapkan, dibentuk dengan variabel tanah, bangunan dan peralatan (PPE), intangible, dan provisi tidak lancar.

$\frac{L T A C C i, t}{T A i, t-1}=\eta 1\left(\frac{1}{T A i, t-1}\right)+\eta 2\left(\frac{P P E i, t}{T A i, t-1}\right)+\eta 3\left(\frac{I N T i, t}{T A i, t-1}\right)+\eta 4\left(\frac{N C P i, t}{T A i, t-1}\right)+\varepsilon i, \mathrm{t}$

Keterangan:

LTACC $_{\text {it }} \quad$ : Long term accruals discretionary perusahaan i tahun $\mathrm{t}$ (didapat dari persamaan 3)

TA i,t-1 : Total aktiva perusahaan i pada tahun $\mathrm{t}-1$

PPEi,t : Nilai bruto tanah, bangunan dan peralatan perusahaan $\mathrm{i}$ pada tahun $\mathrm{t}$

INT $\mathrm{i}, \mathrm{t} \quad$ : Intangible perusahaan $\mathrm{i}$ akhir tahun $\mathrm{t}$

NCP i,t : Provisi tidak lancar perusahaan i tahun $\mathrm{t}$

Eit $\quad$ : error untuk perusahaan i tahun $\mathrm{t}$

Metode yang sama dengan metode penghitungan total dan short term discretionary accruals, masih digunakan dalam mengukur long term discretionary accruals (LTDSCC).

LTDACC $\mathrm{i}, \mathrm{t}=\frac{\text { LTACCi,t }}{T A i, t-1}-\left[\mathrm{h} 1\left(\frac{1}{T A i, t-1}\right)+\mathrm{h} 2\left(\frac{P P E i, t}{T A i, t-1}\right)+\mathrm{h} 3\left(\frac{\text { INTi,t }}{T A i, t-1}\right)+h 4\left(\frac{N C P i, t}{T A i, t-1}\right)\right]$

Pengukuran Manajemen Laba Aktivitas Riil

Tingkat arus kas operasi abnormal

$\frac{C F O i, t}{A s s e t s i, t-1}=k 1 \frac{1}{A s s e t s i, t-1}+k 2 \frac{\text { Salesi, } t}{\text { Assetsi,t-1 }}+k 3 \frac{\Delta 1 \text { Salesi,t }}{\text { Assetsi,t-1 }}+\varepsilon \mathrm{i}, \mathrm{t}$

Arus kas operasi abnormal merupakan nilai absolut dari CFO actual dikurangi tingkat CFO normal yang dihitung dari koefisien model regresi. 
Keterangan:

CFOit : Arus kas operasi perusahaan i pada tahun $\mathrm{t}$

Sales it : Penjualan bersih perusahaan i pada tahun $\mathrm{t}$

$\Delta$ Sales it - 11 : Pertumbuhan penjualan bersih perusahaan i dari tahun $\mathrm{t}-2 \mathrm{ke} \mathrm{t}-1$

$\Delta$ Sales it : Pertumbuhan penjualan bersih perusahaan i dari tahun $\mathrm{t}-1 \mathrm{ke} \mathrm{t}$

Assets i, t-1 : Total aset perusahaan i pada tahun t-1

\section{b. Kinerja Keuangan}

Dalam penelitian ini kinerja keuangan diukur menggunakan indikator leverage, likuiditas, profitabilitas dan aktivitas. Kinerja keuangan leverage diukur dengan rumus yang digunakan dalam penelitian Zamri et al. (2013) dan Fanani (2014) yakni dengan mencari rasio total hutang terhadap total aset. Kinerja keuangan likuiditas diukur dengan rumus current ratio yakni rasio aset lancar terhadap hutang lancar seperti yang digunakan dalam penelitian Halabi dan Abbadi (2014) dan Kontorizos (2015). Kinerja keuangan profitabilitas diukur dengan rumus return onassets (ROA) yakni rasio laba terhadap total aset perusahaan seperti yang digunakan dalam penelitian Fanani (2014), Perwitasari (2014) dan Kontorizos (2015). Kinerja keuangan aktivitas diukur dengan rumus perputaran aset tetap yakni rasio penjualan terhadap total aset perusahaan (Hanafi dan Halim, 2000:81).

\section{c. Karakteristik Perusahaan}

Berikut pengukuran karakteristik perusahaan yang digunakan dalam penelitian ini. Size atau ukuran perusahaan diukur dengan logaritma natural dari total aset perusahaan seperti yang digunakan dalam penelitian $\mathrm{Gu}$ et al. (2005) dan Uwuigbe et al. (2015). Growth atau pertumbuhan perusahaan diukur dengan pertumbuhan aset \{(total assets lagged total assets) /total assets $\}$, seperti yang digunakan dalam penelitian Gu et al (2005). Age atau umur perusahaan diukur dengan umur perusahaan ini mulai dari perusahaan tersebut didirikan sampai dengan penelitian ini dilakukan ( $\mathrm{Gu}$ et al., 2005) dan (Zen dan Herman, 2007). Volatilitas laba diukur dengan EBITDA (Earning Before Interest Depreciation and Amortization) dari tahun perusahaan dihitung dengan rumus $=\sigma /$ Total Asset tahun $\mathrm{t} * 100 \%$ di mana $\sigma$ adalah standar deviasi EBITDA tiap 3 tahun (Baskoro dan Wardani, 2014). Diversifikasi perusahaan dalam penelitian ini diukur dengan mencari diversifikasi perusahaan secara operasi. Diversifikasi operasi diukur dengan Index Herfindahl $\left\{(\Sigma \text { SSales/sales })^{2}\right\}$ seperti pengukuran yang digunakan dalam penelitian Jiraporn et al. (2005) dan Kusumaningtyas dan Yendrawati (2015).

\section{d. Struktur Kepemilikan}

Dalam penelitian ini struktur kepemilikan diukur dengan menggunakan empat indikator yakni kepemilikan terkonsentrasi, kepemilikan intitusional, kepemilikan manajerial dan kepemilikan asing. Struktur kepemilikan di Indonesia termasuk kepemilikan terkonsentrasi. Indikator ini diwakili dengan dummy, dimana nilai 1 untuk kepemilikan terkonsentrasi tinggi (kepemilikan saham pemegang saham terbesar $>50 \%$ ) dan 0 untuk kepemilikan konsentrasi rendah (kepemilikan saham pemegang saham terbesar $<50 \%$ ), seperti pengukuran yang dilakukan dalam penelitian Verawati dan Muid (2011). Kepemilikan institusional diukur dengan persentase saham yang dimiliki oleh investor institusional (Verawati dan Muid, 2011) dan (Diniartika dan Nafasti, 2013). Kepemilikan manajerial diukur dengan persentase jumlah kepemilikan saham yang dimiliki pihak manajemen dari seluruh jumlah saham perusahaan yang beredar (Mahariana dan Ramantha, 2014). Kepemilikan asing diukur dengan proporsi saham biasa perusahaan yang dimiliki oleh perorangan, badan hukum, pemerintah serta bagian-bagiannya yang berstatus luar negeri (Verawati dan Muid, 2011). 


\section{e. Relevansi Nilai Informasi Akuntansi}

Pengujian relevansi nilai dalam penelitian ini menggunakan model Ohlson (1995). Model tersebut mengggambarkan harga pasar (P) surat berharga sebagai fungsi nilai buku per lembar saham (BVEPS) dan laba per lembar saham (EPS). Pada penelitian ini selain laba dan nilai buku ditambahkan juga arus kas dari operasi per lembar saham (CFPS) sebagai indikator relevansi nilai informasi akuntansi (Adhani dan Subroto, 2015). Berikut persamaan yang digunakan untuk mengukur relevansi nilai informasi akuntansi.

$$
\text { Pit }=\beta 0+\beta 1 E P S i t+\beta 2 B V E P S i t+\beta 3 C F P S i t+\text { eit }
$$

Keterangan:

Pit $\quad=$ Harga saham perusahaan i pada 3 bulan setelah $\mathrm{t}$

$\beta \quad=$ Konstanta

EPSit $\quad=$ Laba per lembar saham

BVEPSit $\quad=$ Nilai buku per lembar saham

CFPSit $\quad=$ Arus kas operasi per lembar saham

\section{f. Good Corporate Governance}

Dalam penelitian ini $G C G$ diukur dengan menggunakan lima indikator yang diadopsi dari penelitian Shan (2014) namun disesuaikan dengan kondisi pasar modal di Indonesia, yakni ukuran dewan direksi, ukuran dewan komisaris, ukuran komisaris independen, ukuran komite audit dan auditor big twenty six. Auditor big twenty six merupakan $26 \mathrm{KAP}$ besar di Indonesia yang pernah mengaudit emiten BEI selama periode 2010-2014 (Mustofa, 2014).

\section{Prosedur Analisis}

Prosedur analisis data dalam penelitian ini menggunakan analisis Partial Least Square (PLS) merupakan metode analisis yang tidak didasarkan banyak asumsi (Ghozali, 2006). Dengan metode PLS maka model yang diuji dapat mempergunakan asumsi data tidak harus berdistribusi normal, skala pengukuran dapat berupa nominal, ordinal, interval, maupun rasio, jumlah sampel tidak harus besar, indikator tidak harus dalam bentuk reflektif (dapat berupa indikator reflektif dan formatif) dan model tidak harus berdasarkan pada teori (Ghozali, 2006). Dalam analisis ini dilakukan uji outer model dan inner model dengan model diagram jalur sebagai berikut:

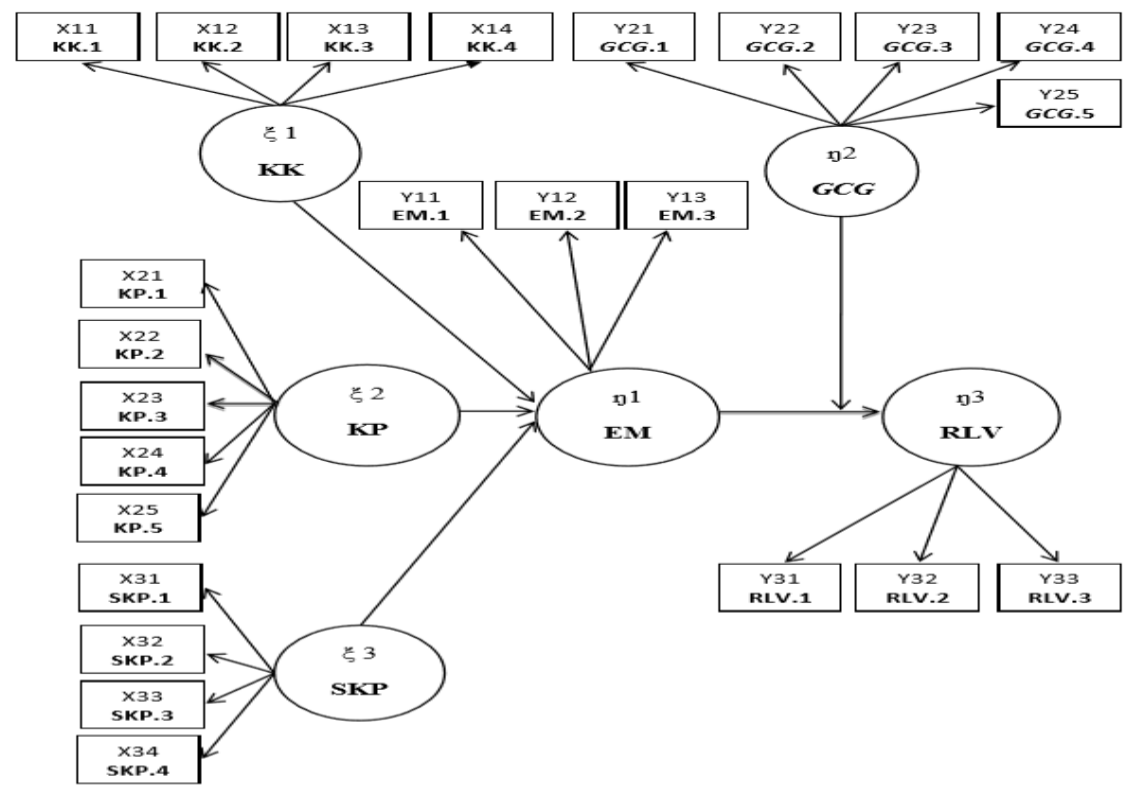

Gambar 2: Model Diagram Jalur 


\section{Hasil dan Pembahasan}

\subsection{Evaluasi Terhadap Hasil Pengujian Statistik}

Hasil pengujian terhadap outer model menunjukkan bahwa nilai loading factor di atas 0.5 yang berarti bahwa indikator termuat dalam variabel laten dan telah memenuhi validitas konvergen (convergent validity) sebagaimana ditunjukkan pada tabel 1 .

Tabel.1 Nilai Outer Loading

\begin{tabular}{cccc}
\hline Variabel Laten & Indikator & Loading Factor & Keterangan \\
\hline EM & EM1 & 0,6449 & valid \\
& EM2 & 0,8864 & valid \\
GCG & GCG1 & 0,8904 & valid \\
& GCG2 & 0,8632 & valid \\
KK & KK3 & 0,6317 & valid \\
& KK4 & 0,8882 & valid \\
KP & KP5 & 1,000 & valid \\
RLV & RLV1 & 0,9095 & valid \\
& RLV3 & 0,7864 & valid \\
SKP & SKP1 & 0,8743 & valid \\
& SKP2 & 0,7553 & valid \\
\hline
\end{tabular}

Sumber: Data Sekunder (diolah)

Validitas diskriminan untuk indikator reflektif yang dinilai dari square root of average variance extacted (akar AVE) masing-masing lebih tinggi dari nilai korelasi antar variabel lainnya (tabel 2), yang berarti bahwa variabel laten mampu memprediksi ukuran pada blok diri sendiri lebih baik dari pada ukuran pada blok lainnya. Hal ini berarti bahwa seluruh variabel memiliki discriminant validity yang tinggi, sehingga semua variabel telah valid digunakan pada tahapan analisis selanjutnya.

Tabel 2. Korelasi antar variabel dan AVE

\begin{tabular}{cccccc}
\hline \multicolumn{1}{c}{ EM } & CGC & KK & KP & RLV \\
\hline GCG & 0,03062 & & & & \\
KK & 0,26347 & 0,03105 & & & \\
KP & $-0,08451$ & $-0,34670$ & $-0,08985$ & & \\
RLV & 0,37874 & 0,37311 & 0,53174 & $-0,07305$ & \\
SKP & 0,37894 & $-0,05247$ & 0,26014 & $-0,33782$ & 0,01069 \\
& & & & & \\
\hline Variabel Laten & AVE & Akar AVE & & & \\
\hline EM & 0,6008 & 0,7751 & & & \\
GCG & 0,7701 & 0,8775 & & & \\
KK & 0,5940 & 0,7707 & & & \\
KP & 1,0000 & 1,0000 & & & \\
RLV & 0,7228 & 0,8502 & & \\
SKP & 0,6674 & 0,8170 & & \\
\multicolumn{2}{c}{ Sumber: Data Sekunder (diolah) }
\end{tabular}

Hasil pengujian terhadap model struktural (inner model) disajikan pada disajikan pada tabel 3, sedangkan output grafis disajikan pada gambar 2. Berdasarkan hasil pengujian menunjukkan bahwa semua hipotesis diterima karena nilai $\mathrm{T}$ statistik $>1,96$ dengan arah hubungan positif, kecuali hipotesis kelima negatif. Namun demikian hasil pengujian menunjukkan hipotesis kedua tidak berpengaruh signifikan karena karena nilai $\mathrm{T}$ Statistik $<$ dari 1,96. 
Tabel 3. Ringkasan Hasil Pengujian Model Struktural

\begin{tabular}{lcccc}
\hline \multicolumn{1}{c}{ Hubungan Variabel } & Hipotesis & Koefisien & T Statistik & Kesimpulan \\
\hline $\mathrm{KK} \rightarrow \mathrm{EM}$ & $\mathrm{H} 1$ & 0,177 & 2,625 & Signifikan \\
$\mathrm{KP} \rightarrow \mathrm{EM}$ & $\mathrm{H} 2$ & 0,050 & 0,664 & Non signifikan \\
$\mathrm{SKP} \rightarrow \mathrm{EM}$ & $\mathrm{H} 3$ & 0,350 & 4,195 & Signifikan \\
$\mathrm{EM} \rightarrow \mathrm{RLV}$ & $\mathrm{H} 4$ & 0.378 & 4,882 & Signifikan \\
$\mathrm{EM}$ * GCG $\rightarrow$ RLV & $\mathrm{H} 5$ & -0.204 & 2.095 & Signifikan \\
\hline \multicolumn{4}{c}{ Sumber: Data Sekunder (diolah) }
\end{tabular}

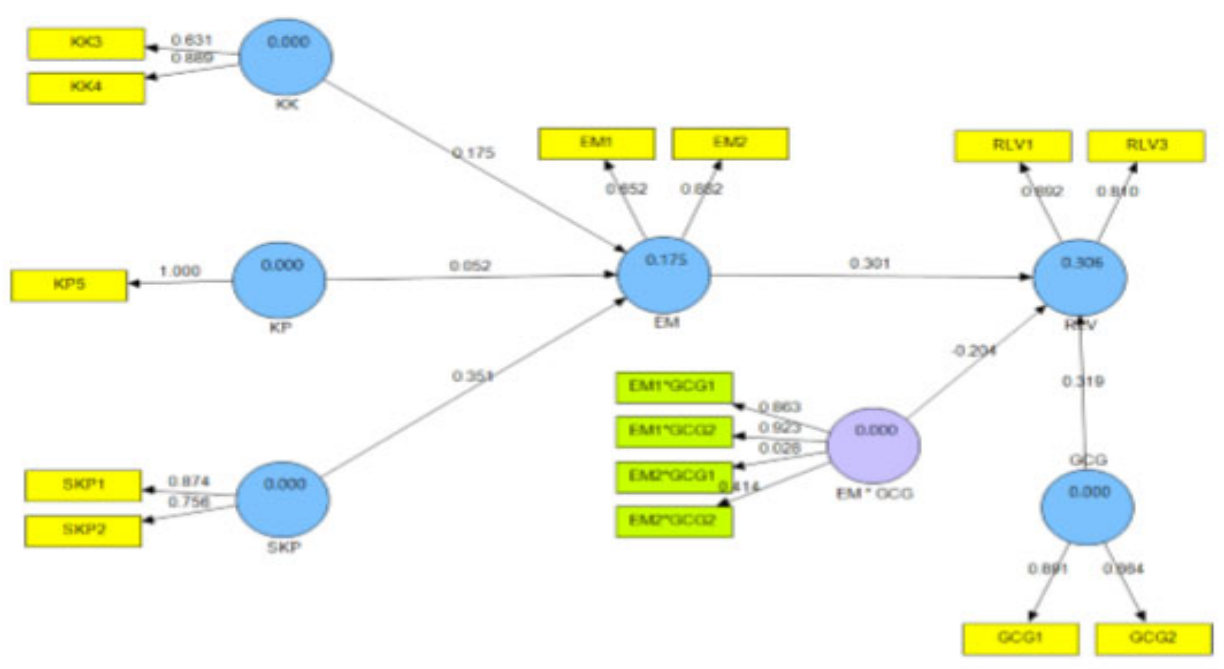

Gambar 2. Algorithma Inner Model dengan Moderasi

Penilaian Kelayakan Model (Goodness of Fit Model) menggunakan R Square $\left(\mathrm{R}^{2}\right)$, Predictive Relevance $\left(\mathrm{Q}^{2}\right)$ dan Effect Size $\left(F^{2}\right)$ disajikan pada tabel 4 berikut ini.

Tabel 4. Goodness of Fit

\begin{tabular}{ccccc}
\hline Konstruk & $\mathbf{R}^{\mathbf{2}}$ Include & $\mathbf{R}^{\mathbf{2}}$ Exclude & $\boldsymbol{F}^{\mathbf{2}}$ & Kategori \\
\hline KK & 0,139 & 0,093 & 0,053 & Moderat \\
KP & & 0,134 & 0,006 & Kecil \\
SKP & & 0,068 & 0,082 & Moderat \\
\hline Sumbr:
\end{tabular}

Sumber: Data Sekunder (diolah)

Nilai R Square $\left(\mathrm{R}^{2}\right)$ pada penelitian ini adalah sebesar 0.139 untuk pengaruh simultan KK, KP dan SKP, artinya variasi nilai variabel EM mampu dijelaskan oleh variasi nilai variabel KK, KP dan SKP adalah sebesar 13.9\%. Sedangkan nilai R Square untuk pengaruh EM terhadap RLV adalah sebesar 0.115, artinya variabel nilai variabel RLV mampu dijelaskan oleh variasi nilai EM adalah sebesar $11.5 \%$.

$\mathrm{Q}^{2}$ predictive relevance untuk model struktural mengukur seberapa baik nilai observasi dihasilkan oleh model dan juga estimasi parameternya. Hasil perhitungan nilai $\mathrm{Q}^{2}$ predictive relevance sebesar 0.238 . Karena nilai $\mathrm{Q}^{2}$ lebih besar daripada 0 , maka dapat disimpulkan bahwa model yang dihasilkan mempunyai predictive relevance yang baik. Effect size merupakan nilai absolut untuk mengukur kontribusi sebuah variabel predictor terhadap koefisien $\mathrm{R}^{2}$ ketika variabel variabel tersebut dikeluarkan dari model. Perubahan nilai $\mathrm{R}^{2}$ dapat digunakan untuk melihat apakah pengaruh variabel laten eksogen terhadap variabel laten endogen memiliki pengaruh yang substantif. Besarnya effect size $\left(\mathrm{F}^{2}\right)$ untuk variabel KK, KP dan SKP adalah masing-masing sebesar 0.053, 0.006 dan 0.082. Nilai 
effect ketiga variabel tersebut pada model dikategorikan moderat untuk variabel $\mathrm{KK}$ dan SKP, sementara variabel KP pada model dikategorikan kecil.

\subsection{Pembahasan}

\section{Pengaruh Kinerja Keuangan terhadap Manajemen Laba}

Hasil pengujian menunjukkan bahwa terdapat pengaruh kinerja keuangan (KK) terhadap manajemen laba (EM). Kinerja perusahaan sebagai tolok ukur bagi para investor untuk melihat perkembangan perusahaan membuat manajer akan melakukan berbagai cara untuk menampilkan kinerja terbaiknya. Rasio-rasio keuangan yang menjadi tolok ukur kinerja keuangan dapat menjadi indikasi terjadinya manajemen laba. Sejalan dengan hasil penelitian Zamriet et al. (2013), yang menunjukkan bahwa leverage berpengaruh terhadap manajemen laba. Fanani (2014) dan Perwitasari (2014) juga menemukan bahwa leverage dan profitabilitas berpengaruh terhadap manajemen laba. Demikian juga dengan hasil penelitian Halabi dan Abbadi (2014), dan Kontorizos (2015) yang menunjukkan bahwa kinerja keuangan berpengaruh terhadap manajemen laba.

Variabel kinerja keuangan dalam penelitian ini diukur dengan menggunakan 4 indikator, yaitu (1) Leverage, (2) Likuiditas (3) Profitabilitas, dan (4) Aktivitas. Indikator yang paling berpengaruh dalam penelitian ini adalah rasio profitabilitas dan rasio aktivitas. Indikator profitabilitas dalam penelitian ini diukur dengan rasio laba terhadap total aset perusahaan. Perusahaan memiliki tingkat keuntungan atas kegiatan operasi perusahaan dan adanya kelebihan dana dapat digunakan untuk meningkatkan dan mengembangkan aktivitas perusahaan tanpa pemilik perusahaan menggunakan dana pinjaman dari luar ratarata sebesar $12.90 \%$. Nilai ROA yang semakin mendekati 1 berarti semakin baik profitabilitas perusahaan karena setiap aset yang ada dapat menghasilkan laba. Nilai ROA yang rendah akan memotivasi perusahaan untuk melakukan manajemen laba dengan cara meningkatkan laba perusahaan. Hasil penelitian ini menunjukkan bahwa kinerja keuangan dengan indikator profitabilitas berpengaruh positif dan signifikan terhadap manajemen laba. Hasil tersebut memberikan bukti bahwa apabila kinerja perusahaan berada dalam kinerja yang buruk maupun kinerja yang baik, tetap akan memicu manajer bertindak oportunis dengan menaikkan laba atau menurunkan laba akuntansi sesuai dengan kondisi kinerja perusahaan tersebut. Nilai ROA yang tinggi dalam penelitian ini memotivasi perusahaan untuk melakukan manajemen laba dengan cara meminimumkan laba melalui diskresi akrual jangka pendek dan memaksimalkan laba melalui diskresi akrual jangka panjang. Hasil penelitian ini mendukung hasil penelitian yang dilakukan oleh Perwitasari (2014) yang menunjukkan profitabilitas berpengaruh positif terhadap manajemen laba.

Indikator aktivitas dalam penelitian ini diukur dengan perputaran aset tetap perusahaan dengan melihat perbandingan penjualan terhadap total aset perusahaan, yang ditunjukkan dengan nilai rata-rata sebesar 1.065 yang mengindikasikan kemampuan perusahaan menggunakan aset nya secara efektif untuk meningkatkan penjualan sangat tinggi. Hasil penelitian ini menunjukkan bahwa kinerja keuangan dengan indikator aktivitas berpengaruh positif dan signifikan terhadap manajemen laba. Nilai perputaran aset yang tinggi dalam penelitian ini memotivasi perusahaan untuk melakukan manajemen laba dengan cara memaksimalkan laba melalui diskresi akrual jangka pendek maupun melalui diskresi akrual jangka panjang. Manajemen melakukan tindakan manajemen laba agar kinerja perusahaan terlihat lebih baik sesuai dengan ekspetasi manajemen. Pengaruh aktivitas terhadap manajemen laba tersebut dikarenakan manajemen ingin menunjukkan efektivitas pemanfaatan aset dalam menghasilkan penjualan agar kinerja keuangan perusahaan terlihat baik. Hasil penelitian ini dapat berarti bahwa pemilik saham menilai kinerja manajer berdasarkan kemampuannya dalam menghasilkan laba perusahaan, sebaliknya manajer berusaha memenuhi tuntuan prinsipal untuk menghasilkan laba yang 
maksimal dan memanfaatkan aset dalam menghasilkan penjualan agar mendapatkan kompensasi atau insentif yang diinginkan.

\section{Pengaruh Karakteristik Perusahaan terhadap Manajemen Laba}

Hasil pengujian hipotesis kedua menunjukkan bahwa karakteristik perusahaan berpengaruh positif tetapi tidak signifikan terhadap manajemen laba. Variabel karakteristik perusahaan dalam penelitian ini diukur dengan menggunakan lima indikator yaitu (1) size, (2) growth, (3) age, (4) volatilitas laba, dan (5) diversifikasi perusahaan. Hasil penelitian ini menunjukkan bahwa size sebagai indikator untuk variabel karakteristik perusahaan tidak berpengaruh terhadap manajemen laba. Rata-rata perusahaan manufaktur yang dijadikan sampel dalam penelitian ini mempunyai asset yang cukup tinggi yaitu 14 triliun. Perusahaan besar lebih menikmati manfaat ekonomi dan lingkup, cenderung menjadi dewasa dan beroperasi dalam keadaan stabil dan volatilitas operasi di sektor bisnis berbeda mengimbangi satu sama lain sehingga perusahaan besar berpeluang untuk terlibat dalam manipulasi laba karena kerumitan usaha dan kompleksitas bagi pengguna, namun tidak demikian dalam penelitian ini. Hasil tersebut sesuai dengan size hyphotesis yang dikemukakan Watt dan Zimmerman (1986). Secara politis perusahaan sedang dan besar lebih mendapat perhatian dari berbagai pihak termasuk para analis keuangan dan pemerintah dibandingkan dengan perusahaan kecil. Pelaporan laba yang menyolok akan mendapat perhatian dari institusi pemerintahan terutama konsekuensi atas pajak dan biaya sosial lainnya. Hal ini juga memperkuat alasan mengapa growth, age dan volatilitas laba perusahaan sebagai indikator variabel karakteristik perusahaan tidak berpengaruh terhadap manajemen laba. Variabilitas yang lebih tinggi dari akrual tidak terjadi walaupun tingkat pertumbuhan perusahaan lebih tinggi, umur perusahaan lebih lama dan tingkat perubahan laba yang tinggi.

Indikator lain yang paling berpengaruh terhadap manajemen laba adalah diversifikasi perusahaan. Hasil penelitian ini mendukung hasil penelitian yang dilakukan oleh Aryati dan Walansendouw (2013) dimana diversifikasi perusahaan tidak berpengaruh terhadap manajemen laba karena krisis yang terjadi pada tahun2008 dan sisa-sisa dampaknya pada tahun-tahun berikutnya yang menyebabkan rata-rata perusahaanperusahaan di Indonesia, terutama yang terdaftar di dalam Bursa Efek Indonesia, secara merata memiliki kecenderungan untuk melakukan manajemen laba dengan tingkat yang relatif sama seberapa banyak pun segmen usahanya. Penelitian ini dilakukan di tahun 2016 dengan data segmentasi operasi perusahaan sampel yang beragam dimana rata-rata perusahaan cenderung memiliki lebih dari satu segmen operasi. Segmen operasi yang lebih banyak menandakan lebih kompleks suatu struktur perusahaan sehingga kompleksitas perusahaan membuat banyak pihak terlibat dalam mengontrol aktivitas perusahaan, dengan demikian aktivitas manajemen laba tidak terjadi dalam perusahaan yang mempunyai banyak segmen operasi.

\section{Pengaruh Struktur Kepemilikan terhadap Manajemen Laba}

Hasil pengujian hipotesis ketiga menunjukkan bahwa struktur kepemilikan berpengaruh terhadap manajemen laba. Pemisahan kepemilikan saham oleh prinsipal dengan pihak lainnya dalam suatu organisasi cenderung menimbulkan konflik keagenan. Kepemilikan saham oleh pihak eksternal ini dapat mengontrol terjadinya manajemen laba. Struktur kepemilikan dalam penelitian ini diukur dengan menggunakan empat indikator yaitu (1) kepemilikan terkonsentrasi, (2) kepemilikan institusional, (3) kepemilikan manajerial, dan (4) kepemilikan asing. Indikator yang paling berpengaruh dalam penelitian ini adalah konsentrasi kepemilikan dan kepemilikan institusional.

Pada prinsipnya, kepemilikan yang terkonsentrasi akan mengurangi tingkat konflik kepentingan antara agen dan principal, hal ini dapat meminimumkan biaya keagenan namun konsentrasi kepemilikan dalam penelitian ini justru berpengaruh positif terhadap 
manajemen laba yang mengindikasikan bahwa semakin terkosentrasi suatu kepemilikan saham maka semakin berpeluang manajemen melakukan manipulasi laba. Sebanyak $85.5 \%$ perusahaan manufaktur yang menjadi sampel dalam penelitian ini merupakan perusahaan yang memiliki saham terkonsentrasi. Hal ini berarti saham-saham pada perusahaan manufaktur yang terkonsentrasi atau tersebar pada beberapa kepemilikan akan memiliki peluang yang sama terjadinya manajemen laba. Tetapi, yang perlu menjadi perhatian adalah pengelolaan laba dapat bersifat efisien, tidak selalu opportunis. Jika pengelolaan laba tersebut efisien maka kekuatan kepemilikan saham yang terkonsentrasi pada satu pemilik justru akan meningkatkan pengelolaan laba.

Kepemilikan institusional dapat menjadi mekanisme yang membatasi manajemen laba. Perusahaan dengan kepemilikan institusional yang besar mengindikasikan kemampuannya untuk memonitor manajemen karena semakin besar kepemilikan institusional maka semakin efisien pemanfaatan aset perusahaan dan diharapkan juga dapat bertindak sebagai pencegahan terhadap pemborosan yang dilakukan oleh manajemen. Nilai rata-rata kepemilikan institusional dalam penelitian ini sebesar 59.137 yang berarti sebanyak $59.13 \%$ perusahaan sudah melakukan pengelolaan perusahaan yang bagus dimana saham institusi yang dimiliki lebih besar dari keseluruhan jumlah saham yang beredar.

Hasil penelitian ini tidak mendukung hasil penelitian yang dilakukan oleh Verawati dan Muid (2011), Diniartika dan Nafasti (2013) yang menunjukkan bahwa terdapat pengaruh yang negatif antara kepemilikan manajerial terhadap manajemen laba. Kepemilikan institusional yang rendah menyebabkan manajemen mempunyai fleksibelitas yang lebih tinggi dalam melakukan kebijakan mengatur laba. Hasil penelitian ini menunjukkan bahwa kepemilikan institusional justru berpengaruh positif terhadap manajemen laba yang artinya semakin tinggi tingkat kepemilikan saham institusi dalam suatu perusahaan maka semakin memperbesar terjadinya manajamen laba. Hal ini mengindikasikan banyak atau sedikitnya hak suara yang dimiliki oleh institusi tidak dapat membatasi manajemen laba yang dilakukan oleh manajemen. Hasil penelitian ini mendukung penelitian yang dilakukan oleh Mahariana dan Ramantha (2014) yang menyatakan kepemilikan institusional adalah pemilik yang lebih memfokuskan pada current earnings. Akibatnya pihak manajemen dapat saja terpicu melakukan tindakan yang akan meningkatkan laba jangka pendek. Adanya kepemilikan institusional menyebabkan manajer terasa terikat untuk memenuhi target laba dari para investor, sehingga manajer akan tetap cenderung terlibat dalam tindakan manipulasi laba.

\section{Pengaruh Manajemen Laba terhadap Relevansi Nilai Informasi Akuntansi}

Hasil pengujian hipotesis keempat menunjukkan bahwa manajemen laba berpengaruh positif dan signifikan terhadap relevansi nilai informasi akuntansi. Manjemen laba dalam penelitian ini diukur dengan menggunakan tiga indikator yaitu (1) short term discretionary accruals, (2) long term discretionary accruals, dan (3) riil. Indikator yang paling berpengaruh dalam penelitian ini adalah short term discretionary accruals dan long term discretionary accruals. Short term dan longterm accruals memiliki karakteristik yang berbeda. Short term accruals memiliki jangka waktu yang relatif pendek untuk dapat kembali, biasanya sampai kuartal pertama atau satu tahun buku, sedangkan long term accruals memiliki jangka waktu lebih dari satu tahun buku untuk kembali (Dechow 1994). Manajer dapat mengambil keuntungan dari perbedaan karakteristik tersebut. Manajer akan menghadapi kesulitan dalam memanipulasi data akuntansi apabila harus me-manage akrual dengan short-term discretionary accruals, karena pasar berharap akrual jenis ini akan kembali secepatnya, sebaliknya manajer akan lebih mudah untuk memanipulasi data akuntansi melalui long term discretionary accruals, karena tindakan manajer tersebut tidak 
dapat dideteksi untuk beberapa periode akuntansi berikutnya (Whelan dan McNamara, 2004).

Nilai rata-rata short term discretionary accruals perusahaan sampel sebesar 0,006 yang berarti perusahaan manufaktur lebih banyak memaksimalkan laba melalui diskresi akrual jangka pendek daripada meminimumkan laba. Short term discretionary accruals memiliki pengaruh positif terhadap relevansi nilai informasi laba dan relevansi nilai informasi arus kas. Hal ini mengindikasikan bahwa manajemen laba yang dilakukan perusahaan dengan short term discretionary accruals justru meningkatkan relevansi nilai laba dan relevansi nilai arus kas. Temuan ini bertolak belakang dengan teori karena seharusnya relevansi nilai informasi akuntansi akan menurun jika terdapat praktik manajemen laba. Pada penelitian ini, perusahaan yang menjadi sampel penelitian tidak hanya perusahaan yang mengalami laba namun juga perusahaan yang mengalami rugi. Rugi sebelum pos luar biasa pada perhitungan akrual tentu saja berpengaruh terhadap variabilitas akrual terlihat dari rata-rata perusahaan yang meminimumkan laba melalui diskresi akrual jangka pendek. Hal ini dapat menjadi alasan walaupun terdapat praktik manajemen laba namun relevansi nilai informasi akuntansi tetap tinggi karena sinyal yang diberikan manajemen terhadap pihak luar dianggap mengandung informasi yang sebenarnya.

Nilai rata-rata long term discretionary accruals perusahaan sampel bernilai positif sebesar 5307 yang berarti perusahaan manufaktur lebih banyak memaksimalkan laba melalui diskresi akrual jangka panjang daripada meminimumkan laba. Manajemen laba melalui long term discresionary accrual justru menaikan relevansi nilai laba. Dengan hasil yang demikian maka investor sebagai pihak yang berkepentingan belum begitu merespon secara signifikan dengan adanya manajemen laba melaui long term accrual. Menurut Whelan dan McNamara (2004) hal ini dapat disebabkan oleh ketidakmampuan pelaku pasar di Indonesia membedakan bentuk manajemen laba. Hasil penelitian ini mendukung penelitian yang dilakukan oleh Apriyan dan Pasaribu (2015).

Manajemen laba dengan aktivitas riil dalam penelitian ini tidak berpengaruh terhadap relevansi nilai informasi akuntansi. Statistik deskriptif menunjukkan nilai arus kas abnormal rata-rata perusahaan sampel bernilai positif yang berarti arus kas bersih dari aktivitas operasi lebih tinggi dari level normalnya. Nilai arus kas abnormal yang positif dapat disebabkan karena perusahaan melakukan pengelolaan penjualan tanpa memberikan diskon dan memperlunak kredit sehingga arus kas yang masuk lebih tinggi jika dibandingkan dengan penjualan pada kondisi normal. Hal lain yang dapat menjadi alasan arus kas operasi abnormal bernilai positif karena perusahaan melakukan penurunan level produksi. Hasil penelitian mendukung teori pensinyalan yang dikemukakan oleh Jogiyanto (2000:292) dimana informasi yang dipublikasikan sebagai suatu pengumuman akan memberikan sinyal bagi investor dalam pengambilan keputusan investasi. Manajer perusahaan memberikan sinyal kabar baik maupun sinyal kabar buruk kepada pihak luar perusahaan. Manajer melakukan manajemen laba untuk memberikan sinyal kabar buruk dengan tujuan memberikan informasi kepada pasar bahwa manajer mempunyai integritas, bertindak jujur dan mempunyai keyakinan dapat menghadapi masalah yang dihadapi (Widyaningdyah dan Listyana, 2009).

Pengaruh Good corporate governance terhadap Hubungan antara Manajemen Laba dan Relevansi Nilai Informasi Akuntansi

Hipotesis kelima ( $\left.\mathrm{H}_{5}\right)$ menunjukkan bahwa good corporate governance berpengaruh terhadap hubungan antara manajemen laba dengan relevansi nilai informasi akuntansi dengan nilai koefisien path yang diperoleh sebesar -0.204 . Hal ini berarti terdapat pengaruh negatif Good corporate governance $(G C G)$ sebagai variabel yang memoderasi variabel manajemen laba dengan variabel relevansi nilai informasi akuntansi. 
Variabel $G C G$ berpengaruh signifikan dalam memperlemah variabel manajemen laba artinya semakin baik penerapan $G C G$ maka akan menekan praktik manajemen laba oportunis dan meningkatkan relevansi nilai informasi akuntansi. Sebagai bagian integral dari perusahaan, pihak manajemen yang ingin mencapai bentuk sistem yang teratur tentunya akan membutuhkan penerapan $G C G$ secara konsisten (Veno, 2015). Corporate governance berkaitan dengan bagaimana para investor yakin bahwa manajer memberikan keuntungan bagi mereka, dengan kata lain $G C G$ diharapkan dapat berfungsi menekan atau menurunkan biaya keagenan (Amaliah, 2016). Indikator yang paling berpengaruh dalam merefleksikan GCG adalah ukuran dewan direksi dan ukuran dewan komisaris. Keberadaan dewan direksi bertugas sebagai mekanisme pengendali internal utama untuk memonitor para manajer perusahaan. Nilai ukuran dewan direksi $(G C G 1)$ perusahaan sampel dalam penelitian ini memiliki rata-rata sebesar 5.919 yang berarti rata-rata perusahaan sampel memiliki 6 orang dewan direksi. Jumlah dewan direksi yang lebih banyak tidak dapat berfungsi secara optimal dan akan lebih mudah dikontrol oleh manajer, terutama karena dewan direksi sendiri disibukkan oleh masalah koordinasi. Jika manajer dapat mengontrol dewan direksi serta adanya asimetri informasi maka akan lebih leluasa bagi manajer untuk melakukan manajemen laba. Kondisi tersebut dikarenakan jumlah dewan direksi yang terlalu banyak akan mengakibatkan banyak perbedaan kepentingan yang tidak selaras satu dengan yang lainnya, sehingga informasi yang asimetris ini akan memberi kesempatan kepada manajemen untuk melakukan praktik manajemen laba di perusahaan tersebut.

Berdasarkan teori keagenan, dewan komisaris dianggap sebagai mekanisme pengendalian intern tertinggi, yang bertanggung jawab untuk memonitor tindakan manajemen puncak. Pengawasan dilakukan agar kecenderungan manajer untuk melakukan manajemen laba berkurang agar investor tetap memberikan kepercayaan untuk menanamkan investasinya pada perusahaan. Dewan komisaris memiliki peran dalam pengawasan perusahaan secara keseluruhan. Dewan komisaris (board) akan lebih efektif dalam menjalankan tugasnya apabila jumlahnya tidak melebihi tujuh atau delapan orang. Hasil penelitian ini mendukung hasil penelitian yang dilakukan oleh Shan (2014) dimana hasil penelitian menunjukkan bahwa dampak negatif dari relevansi nilai untuk perusahaan yang bergerak di manajemen laba lebih besar dari perusahaan tanpa keterlibatan manajemen laba, dan perusahaan dengan praktik tata kelola perusahaan yang baik lebih mungkin untuk mengontrol manajemen laba yang bersifat realistis dan membatasi manajemen laba yang bersifat oportunistik.

\section{Kesimpulan, Implikasi dan Keterbatasan}

Penelitian ini berhasil membuktikan pengaruh signifikan kinerja keuangan dan struktur kepemilikan terhadap manajemen laba. Kinerja keuangan yang diukur dengan rasio profitabilitas dan rasio aktivitas perusahaan dapat menekan atau justru memicu aktivitas manajemen laba. Struktur kepemilikan yang diproksikan dengan konsentrasi kepemilikan dan kepemilikan institusional berpengaruh terhadap manajemen laba. Penelitian ini tidak menemukan bukti adanya pengaruh karakteristik perusahaan terhadap manajemen laba. Karakteristik perusahaan yang menggambarkan ukuran perusahaan, pertumbuhan perusahaan, umur perusahaan, tingkat volatilitas laba perusahaan dan diversifikasi perusahaan berbeda-beda antara satu perusahaan dengan perusahaan yang lain dan tidak dapat dijadikan tolok ukur bahwa suatu perusahaan untuk melakukan manajemen laba. Penelitian berhasil membuktikan bahwa relevansi nilai informasi akuntansi dipengaruhi oleh manajemen laba dan pengukuran manajemen laba yang paling berpengaruh terhadap relevansi nilai tersebut adalah manajamen laba yang diukur dengan long term discretionary accruals dan manajemen laba yang diukur dengan short term 
discretionary accruals. Selanjutnya penelitian berhasil membuktikan adanya pengaruh negatif Good Corporate Governance yang menjadi moderasi manajemen laba dengan relevansi nilai informasi akuntansi.

Implikasi teoritis dalam penelitian ini menjustifikasi Agency Theory bahwa manajemen sebagai agent dapat memberikan pertanggungjawaban secara transparan kepada pemegang saham yang berkaitan dengan tingkat kinerja keuangan dan struktur kepemilikan saham. Upaya menekan praktik manajemen laba yang diwujudkan melalui dibangunnya sistem pengawasan dan pengendalian sebagai bagian dari prinsip GCG, yaitu menurunnya manajemen laba dalam pengelolaan sebuah perusahaan. Pengaruh informasi terhadap perubahan perilaku pemakai informasi dalam pengambilan keputusan oleh investor menjustifikasi Signaling Theory dalam konteks relevansi nilai informasi akuntansi. Implikasi praktis dari penelitian ini bagi investor untuk membantu menentukan keputusan investasi dengan mengevaluasi informasi yang diumumkan perusahaan secara lebih kritis. Bagi manajemen perusahaan hasil penelitian ini bahan pertimbangan dalam penyusunan rencana kegiatan perusahaan di periode yang akan datang dan untuk mengatur aktivitas perusahaan dengan mempertimbangkan angka-angka yang berkaitan dengan akrual maupun aktivitas riil dalam menentukan kinerja periode berjalan. Dalam aspek regulasi, hasil penelitian ini dapat menjadi dasar dalam menetapkan kebijakan pajak yang berkaitan dengan capaian kinerja yang dihasilkan oleh suatu perusahaan pada setiap periode.

Dalam penelitian ini terdapat keterbatasan yang dapat mempengaruhi hasil penelitian. Keterbatasan tersebut antara lain, penelitian ini menggunakan tiga indikator dalam mengukur manajemen laba yaitu diskresi akrual jangka pendek, diskresi akrual jangka panjang dan aktivitas riil, namun penelitian ini belum bisa menentukan dengan jelas pembagian dari pengukuran manajemen laba untuk setiap perusahaaan sampel secara lebih tegas. Penelitian ini menggunakan diversifikasi perusahaan sebagai indikator dari variabel karakteristik perusahaan hanya dari segi operasi karena keterbatasan informasi mengenai diversifikasi geografis. Penelitian ini juga hanya menggunakan data cross section dengan periode satu tahun, sehingga tidak bisa membandingkan trend manajemen laba dari tahun ke tahun. Penelitian selanjutnya diharapkan bisa menentukan dengan jelas pembagian dari pengukuran manajemen laba untuk setiap perusahaaan sampel secara lebih tegas. Penelitian selanjutnya juga dapat menguji diversifikasi perusahaan selain secara operasi juga secara geografis sehingga dampak yang ditimbulkan dari manajemen laba lebih terlihat. Lebih jauh, penelitian selanjutnya diharapkan dapat menggunakan data cross section dan time series (data panel) sehingga bisa membandingkan trend manajemen laba dari tahun ke tahun.

\section{Referensi}

Adhani, Yunita Sari dan Bambang Subroto. 2015. Relevansi Nilai Informasi Akuntansi. Working Paper. Universitas Brawijaya.

Beneish, M.D. 2001. Earnings Management: A Perspective. Managerial Finance, 27 (12), 3-17.

Dechow, Patricia M., R.G Sloan and A.P Sweeney. 1994. Detecting Earnings Management. The Accounting Review, 70, 193-225.

Diniartika, Mega dan Febrina Nafasti. 2013. Analisis Pengaruh Struktur Kepemilikan, Praktik Corporate Governance, dan Kompensasi Bonus terhadap Manajemen Laba pada Perusahaan Manufaktur yang Terdaftar di BEI. Working Paper. Fakultas Ekonomi Universitas Semarang. 
Fanani, Zaenal. 2014. Karakteristik Perusahaan dan Corporate Governance terhadap Manajemen Laba: Studi Analisis Meta. Jurnal Keuangan dan Perbankan, 18 (2), 181-200.

Fattahi, Razie., Mahmoud Moein Addin \& Yahya Abtahi. 2014. Impact of Earning Management on Value Relevance of Accounting Information of The Firms Listed on The Tehran Stock Exchange. Interdisciplinary Journal of Contemporary Research in Business, 6 (2), 378-392.

Ghozali, Imam. 2006. Aplikasi Analisis Multivariate dengan Program SPSS. Semarang: Badan Penerbit Universitas Diponegoro.

Gu, Zhaoyang., Chi-wen Jevons Lee dan Joshua G. Rosett. 2005. What Determines the Variability of Accounting Accruals? Working Paper. Carnegie Mellon University, Pittsburgh.

Halabi, Nabil Bashir dan Hassan Idrees Al-Abbadi. 2014. The Impact of Applying Financial Performance Indicators on Earnings Management in Manufacturing Companies. European Journal of Business and Management, 6 (24), 80-86

Halim, Julia., Carmel Meiden \& R. L. Tobing. 2005. Pengaruh Manajemen Laba pada Tingkat Pengungkapan Laporan Keuangan pada Perusahaan Manufaktur yang termasuk dalam Indeks LQ 45. Prosiding Simposium Nasional Akuntansi VIII. Solo.

Hanafi, Mamduh M. dan Abdul Halim.1996. Analisis Laporan Keuangan. Yogyakarta: Unit Penerbit dan Percetakan AMP - YPKN.

Jensen, Michael C \& W. H Meckling. 1976. Theory of the Firm: Managerial Behavior, Agency Cost and Ownership Structure. Journal of Financial Economics, 3, 305360.

Jiraporn, Pornsit., Yong Sang Kim., \& Ike Mathur. 2005. Does Corporate Diversification Exacerbate or Mitigate Earnings Management? An Empirical Analysis. International Review of Financial Analysis, 17 (5), 1087-1109.

Kontorizos, Georgios. 2015. Financial Indications Behind Earnings Management Practices in Europe. Tesis. Erasmus University, Rotterdam.

Kusuma, Hadri. 2006. Dampak Manajemen Laba terhadap Relevansi Informasi Akuntansi: Bukti Empiris dari Indonesia. Jurnal Akuntansi dan Keuangan, 8(1), 1-12.

Kusumaningtyas, Ratih dan Reni Yendrawati. 2015. The Effect of Company Diversification Toward Earnings Management Moderated by Managerial Ownership. Jurnal Dinamika Manajemen, 6 (2), 167-175.

Mahariana, I Dewa Gede Pingga dan I Wayan Ramantha. 2014. Pengaruh Kepemilikan Manajerial dan Kepemilikan Institusional pada Manajemen Laba Perusahaan Manufaktur di BEI. E-Jurnal Akuntansi Universitas Udayana, 7 (2), 519-528.

Mustofa, 2014. Manajemen Modern Bisnis Kantor Akuntan. Jakarta : Penerbit PT Kompas Media Pratama.

Ohlson, Jamaes A. 1995. Earnings, Book Values, and Dividends in Equity Valuation.Contemporary Accounting Research, 11(2), 661-687.

Perwitasari, Dian. 2014. Struktur Kepemilikan, Karakteristik Perusahaan dan Manajemen Laba. Jurnal Akuntansi Multiparadigma, 5 (3), 432-441.

Richardson, Vernon J. 2000. Information Asymmetry and Earning Management: Some Evidence. Review of Quantitative Finance and Accounting, 15 (4), 325-347.

Scott, R. William. 2015. Financial Accounting Theory $7^{\text {th }}$ Edition. New Jersey : New Jersey

Shan, Yuan George. 2014. Value Relevance, Earnings Management and Corporate Governance in China. Working Paper. School of Accounting \& Finance, University of Adeleide. 
Sholihah, Himma Putri. 2013. The Effect of Earnings Management on Relevance of Earnings and Book Value. Working Paper. University of Brawijaya, Malang.

Trisnawati, Rina., Wiyadi, \& Noer Sasongko. 2012. Pengukuran Manajemen Laba: Pendekatan Terintegrasi (Studi Komparasi Perusahaan Manufaktur yang Tergabung pada Indeks JII dan LQ 45 periode 2004-2010. Jurnal Publikasi. Universitas Muhammadiyah Surakarta.

Uwuigbe, Uwalomwa., Olubukunola Ranti and Okorie Bernard. 2015. Assessment of The Effects of Firms Characteristics on Earnings Management of Listed Firms in Nigeria. Asian Economic and Financial Review, 5 (2): 218-228.

Veno, Andri. 2015. Pengaruh Asismetri Informasi Terhadap Manajemen Laba dengan Good Corporate Governance Sebagai Variabel Moderasi (Studi Empiris Pada Perusahaan Yang Termasuk Dalam Rangking CGPI periode 2004-2013). Tesis. Program Studi Magister Manajemen Program Pascasarjana Universitas Muhammadiyah Surakarta.

Verawati, Diana \& Dul Muid. 2011. Pengaruh Diversifikasi Operasi, Diversifikasi Geografis, Leverage dan Struktur Kepemilikan terhadap Manajemen Laba. Working Paper.

Watts, R, L., \& Zimmerman, J, L. 1986. Positive Accounting Theory. Prentice Hall: New York.

Whelan, Catherine J. dan Raymond P. McNamara. 2004. The Impact of Earnings Management on the Value Relevance of Earnings and Book Value: A Comparison of Short-term and Long-term Discretionary Accruals. Working Paper. Georgia College \& State University, USA.

Wini, Ni Wayan Septia dan Ida Bagus Putra Astika. 2014. Kemampuan Corporate Governance Memoderasi Pengaruh Manajemen Laba pada Pajak Penghasilan. EJurnal Akuntansi Universitas Udayana, 9 (1), 118-132.

Zamri, Norhayati., Rahayu Abdul Rahman \& Noor Saatila Mohd Isa. 2013. The Impact of Leverage on Real Earnings Management. Procedia Economics and Finance, 7, 86-95.

Zen, Sri Dayanti dan Merry Herman. 2007. Pengaruh Harga Saham, Umur Perusahaan, Profitabilitas Perusahaan terhadap Tindakan Perataan Laba yang Dilakukan oleh Perusahaan Perbankan yang Terdaftar di Bursa Efek Jakarta. Jurnal Akuntansi dan Manajemen, 2 (2), 57-71. 